\title{
INDICATORS AND METRICS FOR E-GOVERNMENT MATURITY MODEL IN CROATIA *
}

\author{
Josipa Perkov ${ }^{1}$, Ante Panjkota ${ }^{2}$ \& Ivona Mikulandra Volić ${ }^{3}$
}

\author{
UDC /UDK: 004.7:35(497.5) \\ JEL classification / JEL klasifikacija: H11 \\ DOI: https://doi.org/10.22598/pi-be/2017.11.2.85 \\ Review / Pregledni rad
}

Received / Primljeno: September, 28, 2017 / 28. rujna 2017

Accepted for publishing / Prihvaćeno za tisak: November 27, 2017 / 27. studenoga 2017.

\section{Summary}

E-government should enable a simple approach to online services, simple communication with public authorities and a reduction of time and costs of different transactions. Implementation and further development of e-government are trends in providing public services in many countries, but there is a big difference in the usage of such services among developed and underdeveloped countries. With the aim of bringing rational decisions about the development of e-government, maturity models are used as a tool for assessing, comparing and benchmarking development and success in the implementation of e-government. When it comes to e-government maturity models, special attention should be given to the complexity of e-government in sociological, technological and organizational issues. This complexity has led to the development of many e-government maturity models with different indicators and metrics. Literature review gives answers to the following research questions: Which indicators and metrics are used in some of the more commonly used and/or discussed e-government maturity models? Are those indicators and metrics applicable for Croatian e-government or is there a need for a special model? The aim of this paper is to highlight those indicators and metrics which are able to objectively measure certain values of e-government and to highlight those that are for now without an

\footnotetext{
The paper was presented at the 2nd International Conference "Business \& Entrepreneurial Economics -BEE2017" which was held in Brijuni from 24 to 26 May 2017 (www.bee-conference.com)

1 Josipa Perkov, MA, Senior Lecturer, University of Zadar, Department of Economics, Zadar, Croatia, E-mail: jperkov@unizd.hr

2 Ante Panjkota, Ph.D, Postdoctoral Researcher, University of Zadar, Department of Economics/ Maritime Department, Zadar, Croatia, E-mail: apanjkot@unizd.hr

3 Ivona Mikulandra Volić, MA, Senior Lecturer, University of Zadar, Department of Economics, Zadar, Croatia, E-mail: imvolic@unizd.hr
} 
absolute measure. The result of this paper is a presentation and analysis of indicators and metrics in some of the most commonly used and/or discussed e-government maturity models. By synthesizing conclusions, this paper gives guidelines for the development of an e-government maturity model in Croatia.

Key words: E-government, online services, indicators, metrics, maturity model.

\section{INTRODUCTION}

Although the use of information technology in government is decades old, ,... eGovernment is an idea raised by former U.S. vice president Al Gore within his vision of linking the citizen to the various agencies of government for getting all kinds of government services in an automated and automatic way, in addition to the completion of the government working itself depending on information and communication networks to reduce costs, improve performance, speed of delivery and effectiveness of implementation." (Almarabeh \& AbuAli, 2010). Madsen et al. (2014) researched the development in leading e-government articles from 2001 to 2010 and concluded that the vast majority of papers in the sample represent an optimistic and positive view of e-government, with effects ranging from improved efficiency, reduced costs, faster services and enhanced quality, to accountability and transparency, increased citizens' trust in government etc. According to a UN report (UNDESA, 2016), e-government has rapidly grown over the past 15 years and is emerging as a powerful tool for supporting the implementation of the 2030 Agenda and the 17 sustainable development goals. Since 2014, all 193 Member States of the UN have delivered some form of online presence with the United Kingdom and Australia topping the ranks in the Electronic Government Development Index (EGDI) in 2016 and Croatia ranked as High-EGDI (ranked 37th of 193).

Siskoes et al. (2014) highlight the importance of measuring and benchmarking eGovernment in order to ensure that e-government results foster economic growth and social cohesion. The global e-government ranking studies vary in the number and types of indicators they use to assess e-government progress. The most often used tool for assessing, comparing and benchmarking the progress and success of e-government implementation in public sector organizations are e-government maturity models (Andersen et al. 2011). When it comes to e-government maturity models, special attention should be put on the complexity of e-government in sociological, technological and organizational issues. This complexity has led to the development of many e-government maturity models with different indicators and metrics. The aim of this paper is to highlight those indicators and metrics which are able to objectively measure certain values of e-government and to highlight those that are for now without an absolute measure. The result of this paper is a presentation and an analysis of indicators and metrics in some of the more commonly used and/or discussed e-government maturity models. By synthesizing conclusions, this paper gives guidelines for the development of an e-government maturity model for Croatia.

The next section is an analytical part based on a literature review which presents the conceptual arguments supporting our choice of indicators and metrics for 
assessing e-government maturity. Next is an analysis based on the literature review of previous research aimed at assessing e-government in Croatia. The last chapter presents the conclusion of our findings, possible limitations, and recommendation for future research.

\section{LITERATURE REVIEW - ASSESSMENT OF E-GOVERNMENT}

\subsection{UN's Benchmarking Studies}

UNDESA has published nine editions of the United Nations E-Government Surveys since 2001. The assessment rates the e-government performance of countries relative to one another, as opposed to being an absolute measurement. It measures e-government effectiveness in the delivery of basic economic and social services to people in six sectors: education, health, labour, employment and environment (UNDESA, 2016).

UN rankings of e-government are based on EGDI index. EGDI is used to measure the readiness and capacity of national administrations to use ICT to deliver public services with the aim of gaining a deeper understanding of the relative position of a country in utilizing e-government for the delivery of public services. While the methodological framework for EGDI has remained consistent across the Survey editions, each edition of the Survey has been adjusted to reflect emerging trends in e-government strategies, evolving knowledge of best practices in e-government, changes in technology and other factors. (UNDESA, 2016). Mathematically, EGDI is a weighted average of three normalized scores on three dimensions of e-government: scope and quality of online services (Online Service Index, OSI), development status of telecommunication infrastructure (Telecommunication Infrastructure Index, TII) and inherent human capital (Human Capital Index, HCI).

OSI for a given country is equal to the actual total score less the lowest total score divided by the range of total score values for all countries. Each of these indicators was standardized via the $\mathrm{Z}$-score procedure to derive $\mathrm{Z}$-score for each component indicator. The primary source of the data is an independent survey questionnaire that assesses each country's national website in the native language, including the national portal, e-services portal, and e-participation portal, as well as the websites of the related ministries of education, labour, social services, health, finance and environment as applicable.

TII is an arithmetic average composite of five indicators. Each of these indicators was standardized via the $\mathrm{Z}$-score procedure to derive $\mathrm{Z}$-score for each component indicator. The primary source of data is International Telecommunication Union (ITU). Indicators and metrics used for TII are presented in Table 1. 
Table 1: Indicators and metrics for OSI

\begin{tabular}{|l|l|}
\hline \multicolumn{1}{|c|}{ Indicator } & \multicolumn{1}{c|}{ Metrics } \\
\hline $\begin{array}{l}\text { Estimated internet users per } \\
100 \text { inhabitants }\end{array}$ & Individuals who have used the Internet from any location in the past three months. \\
\hline $\begin{array}{l}\text { Number of main fixed } \\
\text { telephone lines per } 100 \\
\text { inhabitants }\end{array}$ & $\begin{array}{l}\text { Telephone lines connecting a customer's terminal equipment (e.g., telephone set, } \\
\text { facsimile machine) to the public switched telephone network (PSTN), which has a } \\
\text { dedicated port on a telephone exchange. }\end{array}$ \\
\hline $\begin{array}{l}\text { Number of mobile subscribers } \\
\text { per } 100 \text { inhabitants }\end{array}$ & $\begin{array}{l}\text { Telephone lines connecting a customer's terminal equipment (e.g., telephone set, } \\
\text { facsimile machine) to the public switched telephone network (PSTN), which has a } \\
\text { dedicated port on a telephone exchange. Users of both post-paid subscriptions and } \\
\text { prepaid accounts are included. }\end{array}$ \\
\hline $\begin{array}{l}\text { Number of wireless broadband } \\
\text { subscriptions per } 100 \\
\text { inhabitants }\end{array}$ & $\begin{array}{l}\text { Sum of satellite broadband, terrestrial fixed wireless broadband and active mobile- } \\
\text { broadband subscriptions to the public Internet. }\end{array}$ \\
\hline $\begin{array}{l}\text { Number of fixed broadband } \\
\text { subscriptions per } 100 \\
\text { inhabitants }\end{array}$ & $\begin{array}{l}\text { Fixed subscriptions to highspeed access to the public Internet (a TCP/IP connection), } \\
\text { at downstream speeds equal to, or greater than, 256 kbit/s. }\end{array}$ \\
\hline
\end{tabular}

Source: UNDESA, 2016

$\mathrm{HCI}$ is an arithmetic average composite of four indicators. Each of these indicators was standardized via the Z-score procedure to derive Z-score for each component indicator. The primary source of data is the United Nations Educational, Scientific and Cultural Organization (UNESCO). Indicators and metrics used for HCI are presented in Table 2.

Table 2: Indicators and metrics used for HCI

\begin{tabular}{|l|l|}
\hline \multicolumn{1}{|c|}{ Indicator } & \multicolumn{1}{c|}{ Metrics } \\
\hline Adult literacy rate & $\begin{array}{l}\text { Percentage of people aged 15 years and above who can, with understanding, both } \\
\text { read and write a short simple statement on their everyday life. }\end{array}$ \\
\hline $\begin{array}{l}\text { The combined primary, } \\
\text { secondary and tertiary gross } \\
\text { enrolment ratio }\end{array}$ & $\begin{array}{l}\text { Combined primary, secondary and tertiary gross enrolment ratio, of the total } \\
\text { number of students enrolled at the primary, secondary and tertiary level, regardless } \\
\text { of age, as a percentage of the population of school age for that level. }\end{array}$ \\
\hline Expected years of schooling & $\begin{array}{l}\text { Total number of years of schooling that a child of a certain age can expect to } \\
\text { receive in the future, assuming that the probability of his or her being in school at } \\
\text { any particular age is equal to the current enrolment ratio age. }\end{array}$ \\
\hline Average years of schooling & $\begin{array}{l}\text { Average number of years of education completed by a country's adult population } \\
\text { (25 years and older), excluding the years spent repeating grades }\end{array}$ \\
\hline
\end{tabular}

Source: UNDESA, 2016

According to UNDESA (2016), gaps persist among regions, with 66\% of the 29 countries with very high EGDI being from Europe; while African countries represent 81.2\% of the low-EGDI group. The performance of Africa (average EGDI of 0.2882) and Oceania (average EGDI of 0.4154) is lower than the global average. Asia is at 0.5132 and the Americas at 0.5245, while Europe is at 0.7241. Europe is the leading region in which eGovernment is progressing steadily across the continent. The top 10 e-government 
leaders in Europe are the United Kingdom (1), Finland (5), Sweden (6), the Netherlands (7), Denmark (9t), France (10), Estonia (13), Germany (15), Austria (16), and Spain (17). Croatia was ranked 37th (47th in 2014) on that global survey and was one of the countries that have advanced more than 25 positions in 2016 in E-Participation Index (EPI) ranking (25th in 2016 vs. 97 th in 2014).

\subsection{EU's E-Government Benchmark}

New EU eGovernment Action Plan 2016-2020 offers a vision that „by 2020, public administrations and public institutions in the European Union should be open, efficient and inclusive, providing borderless, personalised, user-friendly, end-to-end digital public services to all citizens and businesses in the EU. Innovative approaches are used to design and deliver better services in line with the needs and demands of citizens and businesses. Public administrations use the opportunities offered by the new digital environment to facilitate their interactions with stakeholders and with each other". It has three policy priorities: to modernize public administrations by using key digital enablers, achieve cross-border mobility through interoperability and facilitate digital interaction between administrations and citizens/businesses for high-quality public services.

The latest, 13th edition of the eGovernment Benchmark (EC, 2016) evaluates the priority areas of the eGovernment Action Plan 2011-2015. EU measures the progress and performance of e-government based on specific indicators clustered within four benchmarks:

- User Centricity - indicates to what extent (information about) a service is provided online and how this is perceived;

- Transparent Government - indicates to what extent governments are transparent regarding:

o their own responsibilities and performance,

$\mathrm{o}$ the process of service delivery and

o personal data involved;

- Cross Border Mobility - indicates to what extent EU citizens can use online services in another country.

- Key Enablers - indicates the extent to which 5 technical pre-conditions are available online: Electronic Identification (e-ID), Electronic documents (e-documents), Authentic Sources, Electronic Safe (e-safe) and Single Sign On (SSO).

All top level benchmarks consisted of multiple sub-indicators measured by a number of questions regarding the quality or quantity of e-government services on a specific aspect. Seven life events that cover the most common domains of public services, a representative for both businesses and citizens were selected for this measurement. The method of choice for the assessment was Mystery Shopping. Mystery Shop- 
pers were trained and briefed to observe, experience, and measure a (public service) process acting as prospective users following a detailed, objective evaluation checklist.

EC (2016) shows that countries from the South-West to the North-East of Europe perform above the European average and are also in most cases showing stronger progress than the European average, while the other European countries are behind the European average on both progress and performance. Progress is measured as the difference in performance between the data available in the last (2014-2015) and the first (2012-2013) complete biennial assessment of e-government surveys. Assessment „reveals progress realised over the past four years on four benchmarks“:

- User Centricity: progress in making public services digital (online availability of services at EU28+ level reached $81 \%$ and online usability $83 \%$ ), but ease of using and speed of using these services online increased by only 1 percentage point since the first assessment in 2012;

- Transparency: general improvement of 8 points over the years, reaching $56 \%$ in 2014-2015, but in large parts of Europe transparent service procedures are still lacking (Score of $47 \%$ at EU28+);

- Cross-border Services: business-related services are more advanced in terms of cross-border mobility than citizen-related services: even if the latter increased more since the first measurement $(+13$ points against +11 for business), business mobility gets a higher score (64);

- Key Enablers: technology is not used to its potential, with benchmark scores of $54 \%$.

Figure 1 illustrates how countries are progressing compared to the EU28+ average of scores for four top level benchmarks. The average was measured as the average of all life events measured in 2012/2013 vs 2014/2015.

Figure 1: Progress of countries compared to the EU28+ average

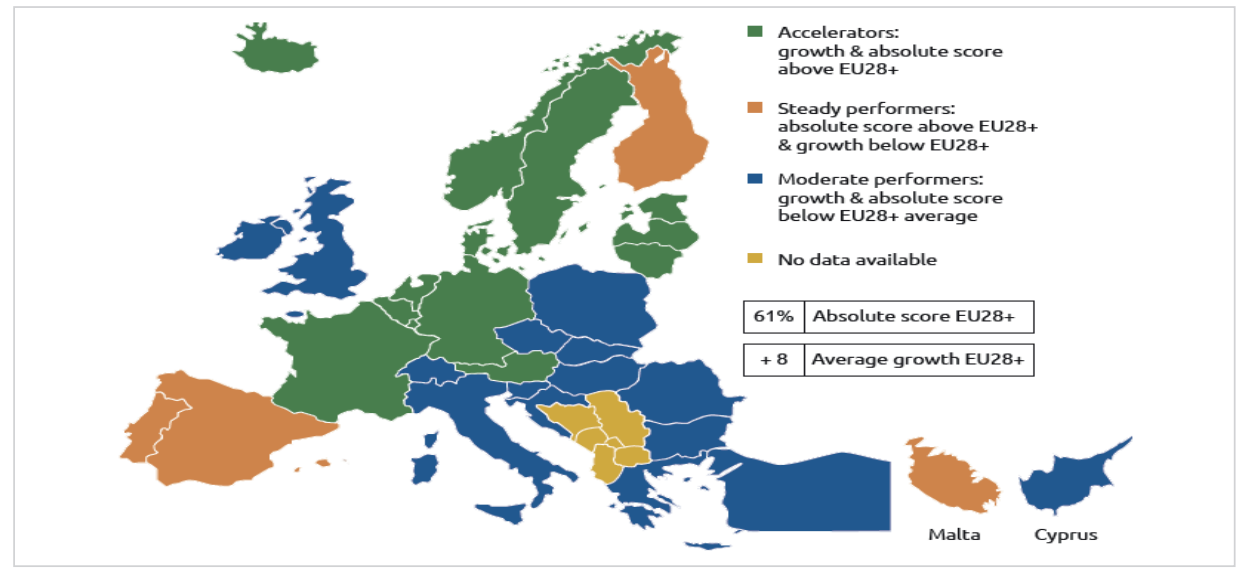

Source: EC, 2016 
For understanding which specific actions countries can take in order to improve their own e-government maturity, EU (EC, 2016) proposes the „bench learning approach". This analysis framework aims at supporting the definition of e-government policies and strategies that a country should implement, through understanding the impact of a specific context on maturity performances, the context-specific differences of countries with similar performances and the differences between countries with similar context and different performances through a two-step analysis. The first step includes measuring maturity performances by using two absolute indicators: Penetration (usage of online services) by using Eurostat as a data source and Digitisation (public administration's efficiency and effectiveness in internal procedures) by using Mystery Shopping as a method of choice for the assessment. The second step evaluates how exogenous factors shape the specific context of individual countries through three relative indicators: Government Supply (the spread of services, including investments and efforts in innovation, diffusion and quality of services), e-government demand (citizens' willingness to use online services) and Environment (readiness of the background - socio-demographic data, ICT Readiness and Governance structure). Table 3 presents five groups of countries with a similar context. Croatia has been placed in group 4 were Portugal represents the benchmark.

Table 3: Group of countries with homogeneous context

\begin{tabular}{|c|c|c|c|c|c|c|c|c|c|}
\hline Group & \multicolumn{7}{|c|}{ Countries } \\
\hline Group 1 & Latvia & Slovenia & Luxembourg & Iceland & Cyprus & Estonia & Lithuania & Malta & \\
\hline Group 2 & Poland & Germany & Italy & France & $\begin{array}{c}\text { United } \\
\text { Kingdom }\end{array}$ & Spain & & & \\
\hline Group 3 & Netherlands & Belgium & Austria & & & & & & \\
\hline Group 4 & Romania & $\begin{array}{c}\text { Czech } \\
\text { Republic }\end{array}$ & Greece & Hungary & Portugal & Bulgaria & Croatia & Slovakia & Turkey \\
\hline Group 5 & Sweden & Ireland & Denmark & Finland & Norway & & & & \\
\hline
\end{tabular}

Source: EC, 2016

By using Penetration and Digitisation as variables, 5 clusters were identified according to the performance of the groups: Neophytes, High Potential, Progressive, Builders and Mature are presented in Figure 2. 
Figure 2: Performance of the groups

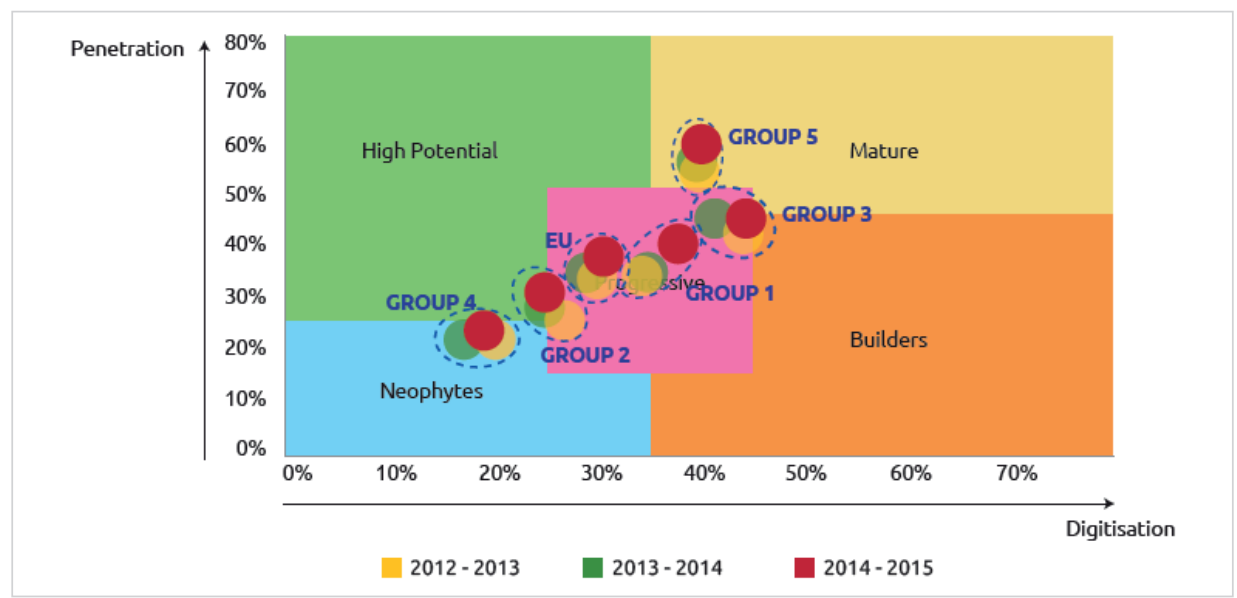

Source: EC, 2016

\subsection{E-Government Maturity Models}

According to Das et al (2016), previous research on e-government conceptualized maturity by using an evolutionary approach: e-government is seen to progress through a series of stages as a function of integration and complexity, or as a function of increasing levels of online activity and customer centricity. E-government maturity models (Andersen et al. 2011) have historically drawn upon stage classification in different academic fields: software process improvement (example: Capability Maturity Model), business economics (example: Product Life Cycle) and information systems (example: Growth Model). E-government maturity models can be divided into the following three types (Concha et al. 2012):

- Governmental models: models developed by governments, consultants and academics to help agencies identify and improve their level of e-government maturity (example: Canadian eGovernment Capacity Check)

- Holistic approach models: models designed to be applied in public services development projects to help agencies identify if an e-government project will be successful or not (example: Capacity Assessment Toolkit)

- Evolutionary e-government maturity models: models focused on the evolution of e-government by using sequential steps, for instance from immature to mature e-government with improved quality (example: the Layne and Lee model and the Andersen and Henriksen model).

Literature review shows that many researchers have already reviewed e-government maturity models, some of them developed by individual researchers and others by institutions, in order to compare and synthesize them (Coursey \& Norris (2008), Fath-Allah et al. (2014), Shahkooh et al. (2008)). Fath-Allah et al. (2014) emphasized that 
although the maturity models present large similarities between them, the features included in those models differ from a maturity model to another. Coursey \& Norris (2008) used empirical investigation to seek the answer to the question whether the models of e-government are correct. They stated that the literature review contains five papers that offer explicit theories or models of e-government relative to its growth and development (Layne and Lee from 2001; Wescott from 2001, Baum and Di Maio from 2000, Ronaghan from 2001 and Hiller and Bélanger from 2001), and described those models as partly descriptive, partly predictive and partly normative. To be specific, their conclusion is „... it appears that, for the most part, the descriptions of these models provide a reasonably accurate portrait of eGovernment in its early stages, from initial Web presence to information provision to interactivity. Beyond this, however, the models become both predictive and normative and their empirical accuracy declines precipitously..." Table 4 shows the steps they found in those five models for predicting the development or evolution of e-government.

Table 4: Models for predicting the development or evolution of e-government

\begin{tabular}{|c|c|c|c|c|c|c|}
\hline Model & Step 1 & Step 2 & Step 3 & Step 4 & Step 5 & Step 6 \\
\hline $\begin{array}{c}\text { Layne and } \\
\text { Lee }\end{array}$ & & Catalogue & Transaction & $\begin{array}{c}\text { Vertical } \\
\text { integration }\end{array}$ & $\begin{array}{l}\text { Horizontal } \\
\text { integration }\end{array}$ & \\
\hline $\begin{array}{c}\text { Baum and } \\
\text { Di Maio }\end{array}$ & & Presence & Interaction & Transaction & Transformation & \\
\hline Ronaghan & $\begin{array}{l}\text { Emerging } \\
\text { presence }\end{array}$ & Enhanced presence & Interactive & $\begin{array}{c}\text { Transactional } \\
\text { government }\end{array}$ & Seamless & \\
\hline $\begin{array}{l}\text { Hiller and } \\
\text { Belanger }\end{array}$ & & $\begin{array}{c}\text { Information } \\
\text { dissemination }\end{array}$ & $\begin{array}{c}\text { Two-way } \\
\text { communication }\end{array}$ & Integration & Transaction & Participation \\
\hline Wescott & $\begin{array}{c}\text { E-mail and } \\
\text { internal } \\
\text { network }\end{array}$ & $\begin{array}{c}\text { Enabled interorganiza- } \\
\text { tional and public access to } \\
\text { information }\end{array}$ & $\begin{array}{c}\text { Two-way } \\
\text { communication }\end{array}$ & $\begin{array}{c}\text { Exchange of } \\
\text { value }\end{array}$ & $\begin{array}{c}\text { Digital } \\
\text { democracy }\end{array}$ & $\begin{array}{l}\text { Joined-up } \\
\text { government }\end{array}$ \\
\hline
\end{tabular}

Source: Coursey \& Norris, 2008

Shahkooh et al. (2008) described and analysed 9 e-government maturity models: Delloite's six-stage model, UN's five-stage model, Layne and Lee's four-stage model, Accenture's five-stage model, Gartner's four-stage model, the World Bank's three-stage model, Asia Pacific six-stage model, West's four-stage model and Hiller and Blanger's five-stage model. Using the Meta-Synthesis approach, they summarized 5 main stages in e-government maturity:

1. Online presence: In this step, the government starts its efforts toward e-government and publishes useful information online.

2. Interaction: Government goes further and citizens can interact with the government by downloading forms, e-mailing to officials.

3. Transaction: In this step, typical services such as tax filing and payment, or driver's license renewal are available.

4. Fully integrated and transformed e-government: In this stage, delivery of government services is redefined by providing a single point of contact to constituents. 
5. Digital democracy: Some services such as online voting, online public forums, and online opinion surveys are available.

This research will also highlight indicators from the research of Coursey \& Norris (2008). They conducted an empirical assessment to test whether e-government models are accurate or useful for understanding the actual development of e-government. Those indicators (presented in Table 5) address the extent to which the government has established official sites online through which they provide information and services, the extent to which online services have been adopted, changes reported as a result of e-government, and reported barriers to the adoption of e-government.

Table 5: Indicators for e-government efforts

\begin{tabular}{|c|c|}
\hline $\begin{array}{l}\text { Indicator for } \\
\text { adoption of websites }\end{array}$ & $\begin{array}{l}\text { - how many local governments have any form of Web presence and whether this figure has } \\
\text { changed over time }\end{array}$ \\
\hline Online services & $\begin{array}{l}\text { - amount of information and services (transactional, nontransactional, financial and non- } \\
\text { financial transactions) that the government (national and local) has provided through their } \\
\text { Web sites }\end{array}$ \\
\hline $\begin{array}{l}\text { Changes resulting } \\
\text { from eGovernment }\end{array}$ & $\begin{array}{l}\text { - cost impact (reduced number of staff, increased non-tax revenues, reduced administrative } \\
\text { costs) and } \\
\text { - noncost impact (reduced time demands on staff, increased demands on staff, reengineered } \\
\text { business processes, more efficient business processes, increased citizen contact with elect- } \\
\text { ed and appointed officials, improved communication with the public and improved custom- } \\
\text { er service) }\end{array}$ \\
\hline $\begin{array}{l}\text { Barriers in } \\
\text { capabilities }\end{array}$ & $\begin{array}{l}\text { - technical barriers (lack of technology/Web staff, lack of technology/Web expertise, lack of } \\
\text { information on eGovernment applications, the website does not accept credit cards, band- } \\
\text { width issues, need to upgrade PCs, networks) } \\
\text { - political and organizational barriers (lack of support from elected officials, lack of collabo- } \\
\text { ration among departments, staff resistance to change, resident resistance to change, lack } \\
\text { of business/resident interest or demand) } \\
\text { - legal barriers (issues related to convenience fees for online transactions, privacy issues, } \\
\text { - security issues) }\end{array}$ \\
\hline
\end{tabular}

Source: Coursey \& Norris, 2008

They have suggested that a survey should be organized every two years which would ask national and local governments about the changes that they attributed to their e-government efforts.

\section{STATE OF PLAY: E-GOVERNMENT IN CROATIA}

First steps in forming the foundations of e-government were taken by the end of 2003 with the establishment of the Central State Administrative Office for e-Croatia in order to implement the e-Croatia 2007 Programme, when according to Šimurina et al. (2008) ,...Croatia was no different than any other transition country in Europe. It was characterized by a low level of administrative transparency, lack of maturity for standardization and measurement, low income and low Internet penetration rate". Their research paper investigates more deeply the history of the development of e-government in Croa- 
tia and provides a comparative analysis of the implementation and possibilities of e-government in Croatia and selected Central and East European (CEE) countries in 2008.

On 19 March 2015, the Croatian Government launched an open data portal http://data.gov.hr/ as an integral part of the e-citizens project. On the day of its launching, 102 data collections were available. One of the open data sets on the website http:// data.gov.hr/dataset/e-gradjani-statistika currently contains the following statistics: the number of unique users of the e-Citizens system (402.393), the number of users of the e-Citizens system by county (presented in Table 6), information about the most used services and information about the credentials used to access the system (5 most used e-services are presented in Table 7). On the Open Government Partnership (OGP) Global Summit in Mexico in 2015, the Croatian project e-Citizens earned Croatia an award as the best European country in terms of open government, in the category pertaining to the advancement of public services. Currently, the Croatian government participates in the project Ensuring Access to Croatian Public e-services within the e-Citizens Platform for EU/EEA Citizens financed by the EU. Latest news about possible cost impacts can be found on the Central Government Portal page and dates from 3 February 2016: the overall aim is to save 1.9 mil kuna.

Table 6: Number of unique users of the e-Citizens system by county (source: National Identification and Authentication System, NIAS, (09/06/2017])

\begin{tabular}{|l|c|c|}
\hline County & Number of unique users & Proportion (\%) \\
\hline City of Zagreb & 126.593 & $31.46 \%$ \\
\hline Primorsko-goranska & 32.332 & $8.03 \%$ \\
\hline Splitsko-dalmatinska & 31.425 & $7.81 \%$ \\
\hline Zagrebačka & 27.577 & $6.85 \%$ \\
\hline Osječko-baranjska & 23.278 & $5.78 \%$ \\
\hline Istarska & 22.545 & $5.60 \%$ \\
\hline Varaždinska & 17.359 & $4.31 \%$ \\
\hline Sisačko-moslavačka & 12.407 & $3.08 \%$ \\
\hline Vukovarsko-srijemska & 11.332 & $2.82 \%$ \\
\hline Zadarska & 11.159 & $2.77 \%$ \\
\hline Međimurska & 11.128 & $2.77 \%$ \\
\hline Krapinsko-zagorska & 10.713 & $2.66 \%$ \\
\hline Brodsko-posavska & 9.793 & $2.43 \%$ \\
\hline Koprivničko-križevačka & 9.258 & $2.30 \%$ \\
\hline Karlovačka & 8.525 & $2.12 \%$ \\
\hline Dubrovačko-neretvanska & 8.350 & $2.08 \%$ \\
\hline Bjelovarsko-bilogorska & 7.045 & $1.75 \%$ \\
\hline Šibensko-kninska & 6.453 & $1.60 \%$ \\
\hline Virovitičko-podravska & 5.383 & $1.34 \%$ \\
\hline Požeško-slavonska & 4.363 & $1.08 \%$ \\
\hline Ličko-senjska & 2.381 & $0.59 \%$ \\
\hline Unknown & 2.587 & $9.64 \%$ \\
\hline TOTAL & 401.986 & \\
\hline
\end{tabular}

Source: National Identification and Authentication System, NIAS, [09/06/2017]) 
Table 7: Total login number, number of unique users and average number of unique users for most used e-services

\begin{tabular}{|l|c|c|c|}
\hline e-service & $\begin{array}{c}\text { Total login } \\
\text { number }\end{array}$ & $\begin{array}{c}\text { Number of } \\
\text { unique users }\end{array}$ & $\begin{array}{c}\text { Average number } \\
\text { of unique users }\end{array}$ \\
\hline Personal User Box (My account) & 3.407 .288 & 289.817 & 12 \\
\hline eRegister & 684.270 & 219.478 & 3 \\
\hline electronic records: Croatian Pension Fund (HZMO) & 709.743 & 157.388 & 5 \\
\hline e-services: Ministry of Interior (MUP) & 340.645 & 144.904 & 2 \\
\hline user pages: Croatian Pension Fund & 800.159 & 117.831 & 7 \\
\hline
\end{tabular}

Source: National Identification and Authentication System, NIAS, (09/06/2017)

According to the official data from the Croatian national portal, many e-services are currently available, the latest offered service dating from 14 April 2017 for a certificate from the Criminal Records. All the services offered can be divided into 10 sections:

- Legal state and security (8)

- Family and living (2)

- Education and training (3)

- Traffic and vehicles (2)

- Free time (1)

- Finance and taxes (3)

- Health (5)

- Labour (7)

- Business (4)

- Housing and environment (2)

Groups of services for business are as follows (detailed description with declared responsibilities and the website can be found in EC (2017):

- Start and grow

- VAT and customs

- Selling abroad

- Staff

- Product requirements

- Public contracts

- Environment

According to EC (2017), Croatia has the following components of e-government infrastructure: 
- Portals (Central Salary System, eCitizen, State administration portal, „HITRO. HR“ portal),

- Networks („eBulletin board and court networking“ project, „StuDOM“ project-System of Local Computer Networks in Students’ Dormitories),

- eIdentification/eAuthentication (FINA eCard, SmartX university card)

- eProcurement (Electronic Public Procurement Classifieds (EPPC), Electronic CIHI card for health care practitioners),

- Knowledge Management (The Central State Office for the Development of the Digital Society, Higher Education Institutions Information System - Undergraduate Studies (ISVU), EUROVOC thesaurus) and

- Other (Personal identification number (OIB) system, Cadastral data browser, eCourt registry, eCREW, eCustoms, Central Database Registry on Personal Data, Multipurpose Spatial Information System and Croatian National Educational Standard (CNES)).

Detailed results for Croatia on all three dimensions of eGovernment covered by the EGDI index are shown in Figures 3, 4 and 5. Figures were based on the UN eGovernment Knowledge DataBase.

Figure 3: OSI for Croatia

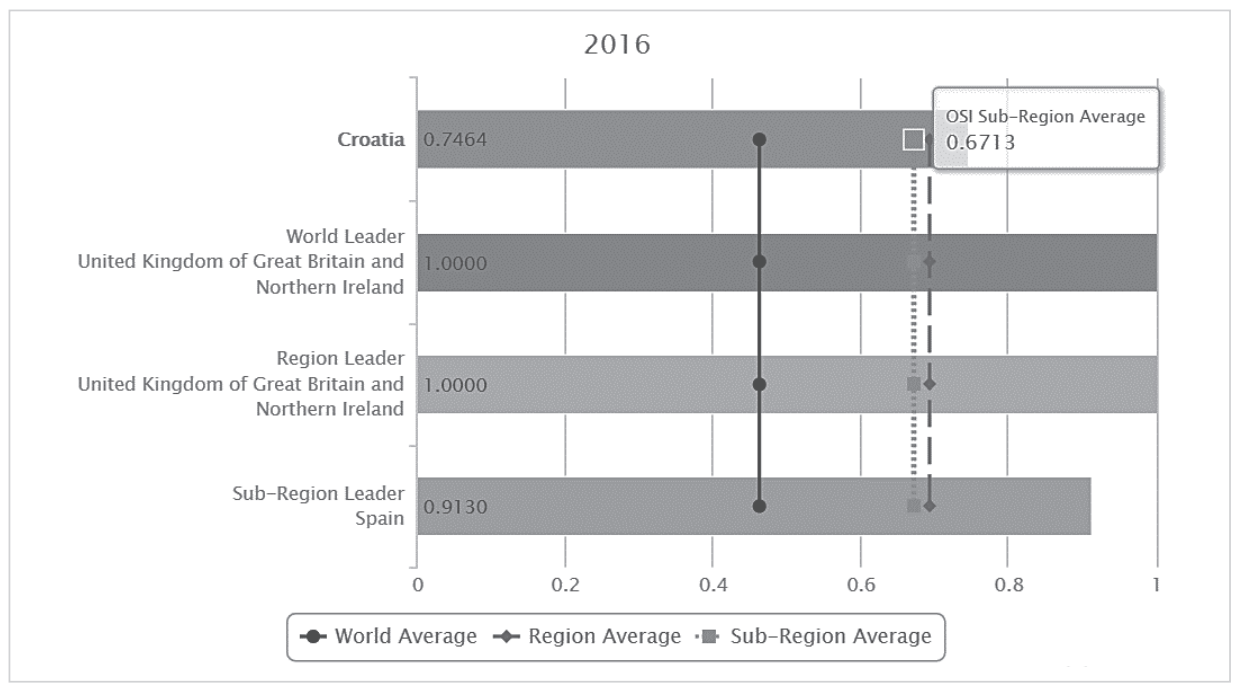

Source: https://publicadministration.un.org/egovkb/en-us/Data/Country-Information/id/42Croatia (15/03/2017) 
Figure 4: TII for Croatia (source: https://publicadministration.un.org/egovkb/en-us/ Data/Country-Information/id/42-Croatia [15/03/2017])

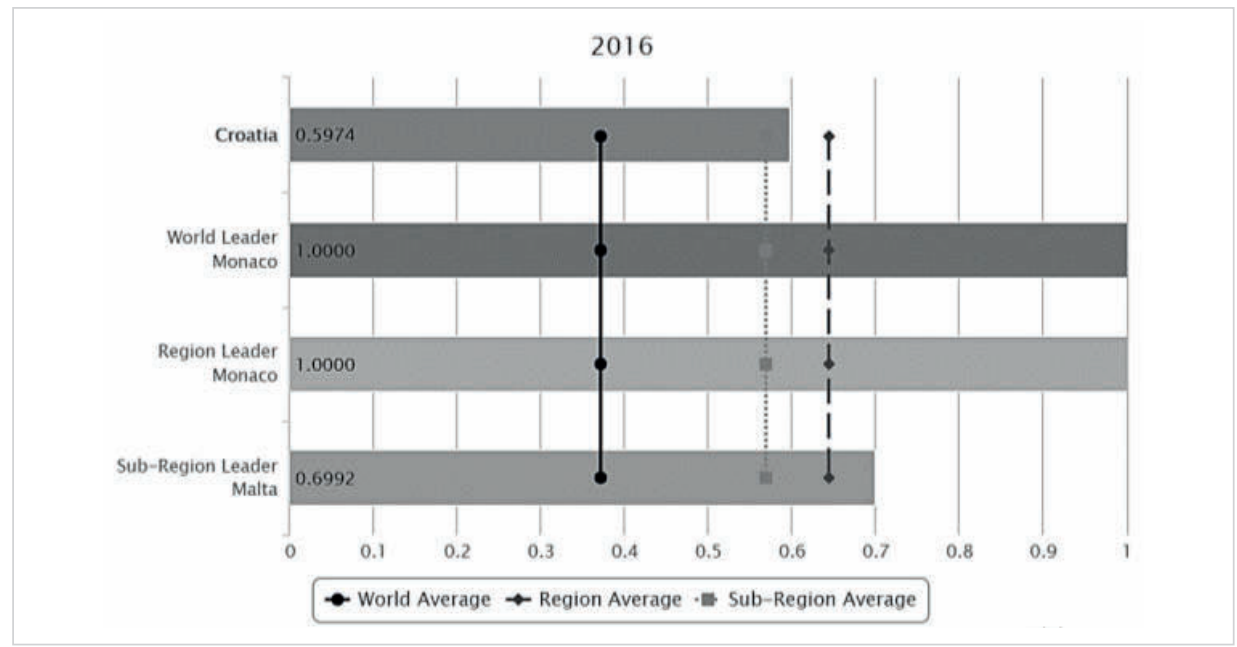

Source: https://publicadministration.un.org/egovkb/en-us/Data/Country-Information/id/42Croatia $(15 / 03 / 2017)$

Figure 5: HCI for Croatia

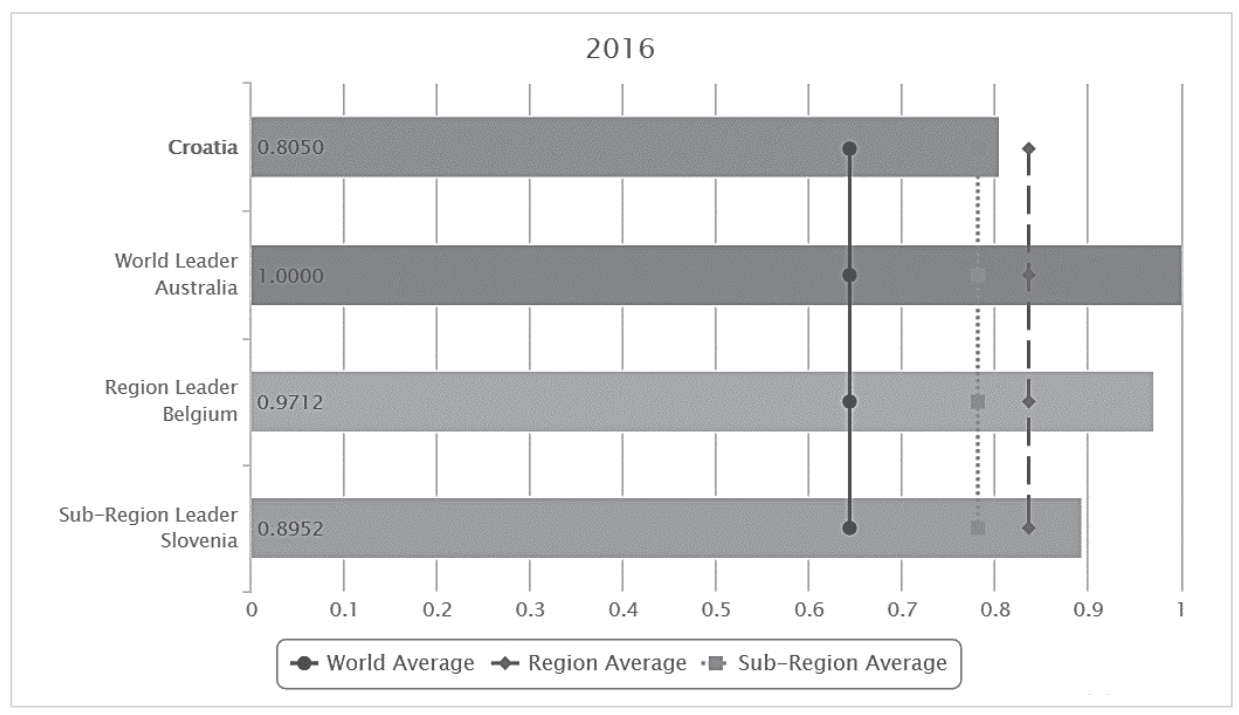

Source: https://publicadministration.un.org/egovkb/en-us/Data/Country-Information/id/42Croatia (15/03/2017)

Figure 6 presents e-government performance across policy priorities in Croatia compared to the EU average. 
Figure 6: Development of eGovernment in Croatia compared to the EU average score

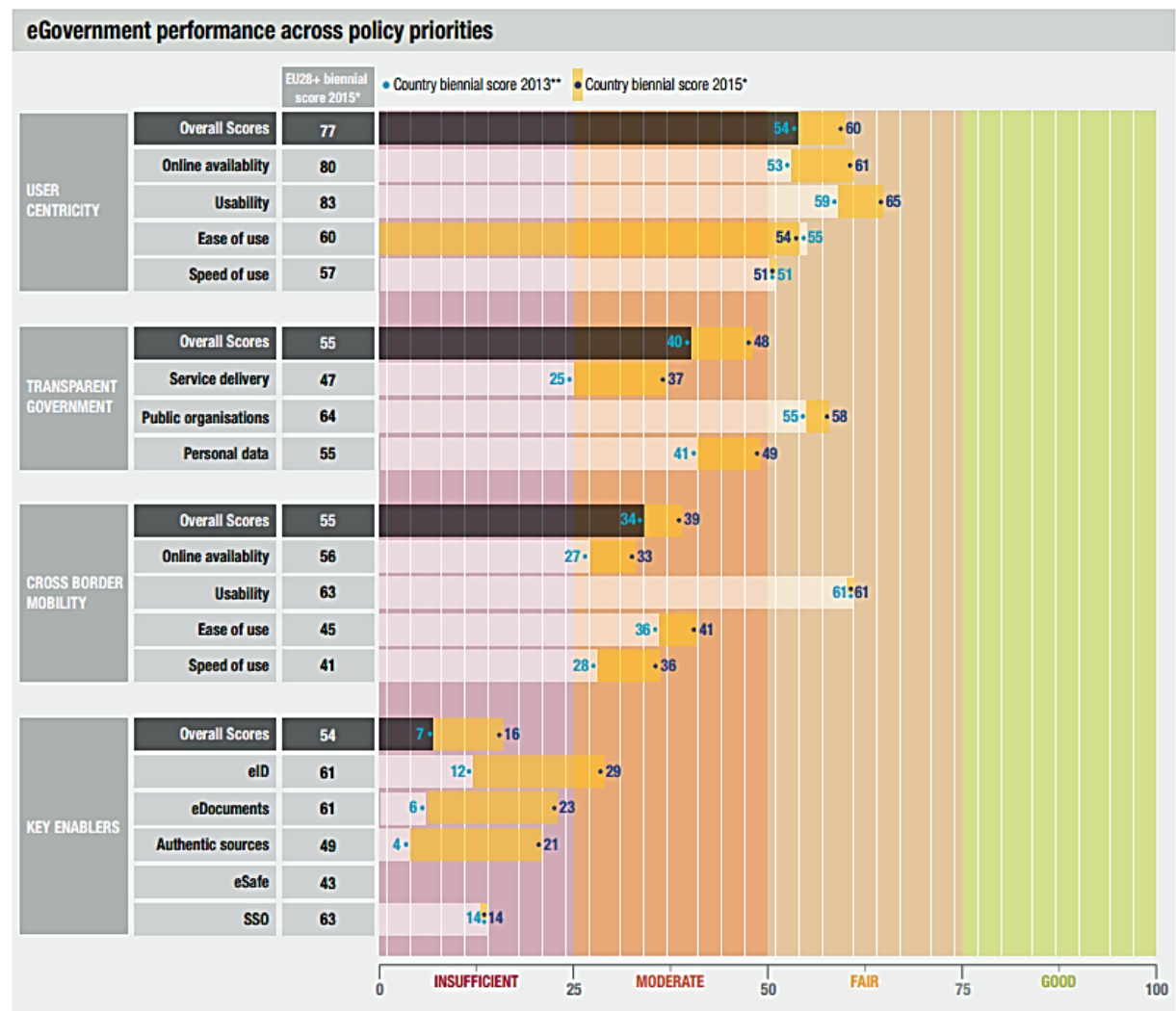

Source: eGovernment Benchmark Report 2016 Country Factsheet Croatia (11/05/2017)

EC created a freely accessible collaborative platform Joinup (https://joinup. ec.europa.eu/), as part of the ISA program that supports the modernisation of the Public Administrations in Europe, which offers several services that aim to help e-government professionals share their experience with each other. From 2014, annual factsheets are part of the project, and they summarize policies and activities related to the implementation and the delivery of digital public services in 34 countries. Figure 7 presents data for the latest Indicators for Croatia compared to the EU average. Statistical indicators used by Eurostat are: percentage of individuals using the Internet for interacting with public authorities in Croatia, percentage of individuals using the Internet for obtaining information from public authorities in Croatia, percentage of individuals using the internet for downloading official forms from public authorities in Croatia and percentage of individuals using the internet for sending filled forms to public authorities in Croatia. 
Figure 7: E-government Indicators for Croatia compared to the EU average

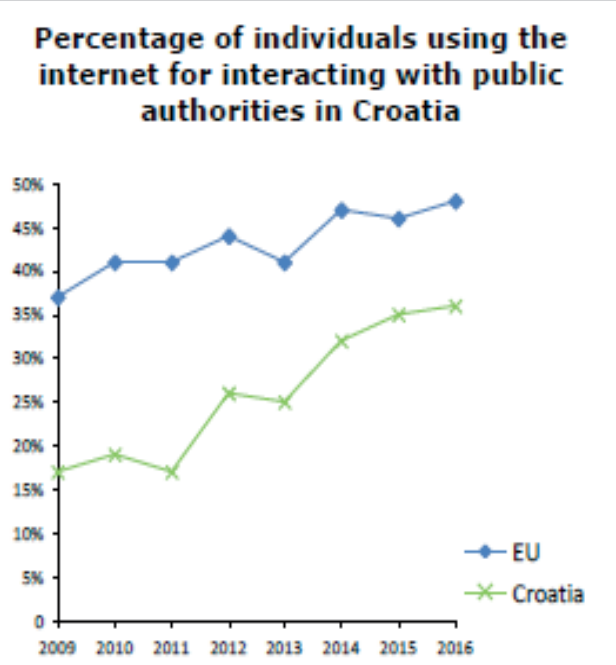

\section{Percentage of individuals using the internet for obtaining information from public authorities in Croatia}

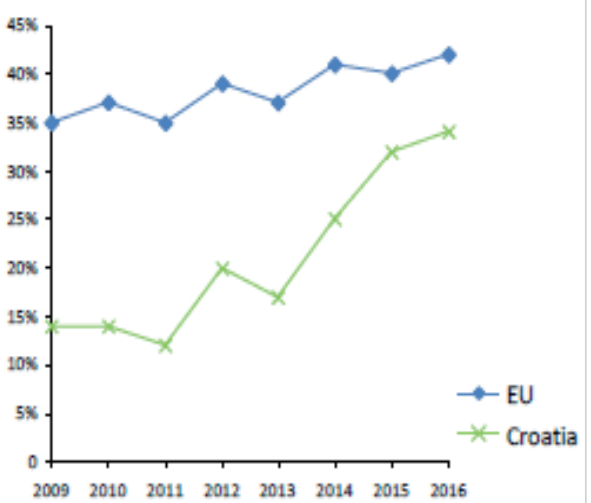

Percentage of individuals using the internet for downloading official forms from public authorities in Croatia

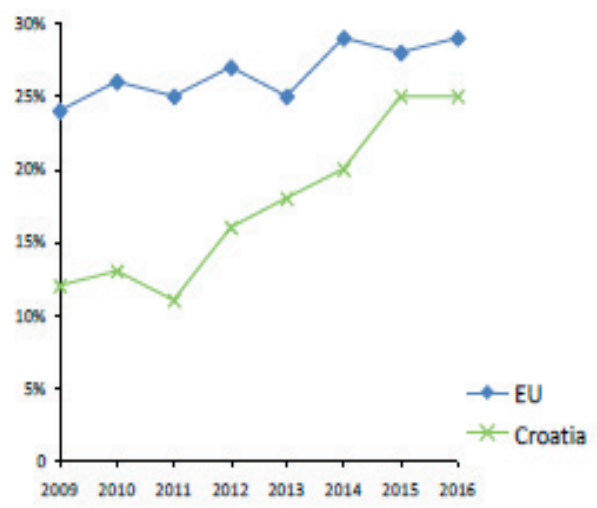

\section{Percentage of individuals using the internet for sending filled forms to public authorities in Croatia}

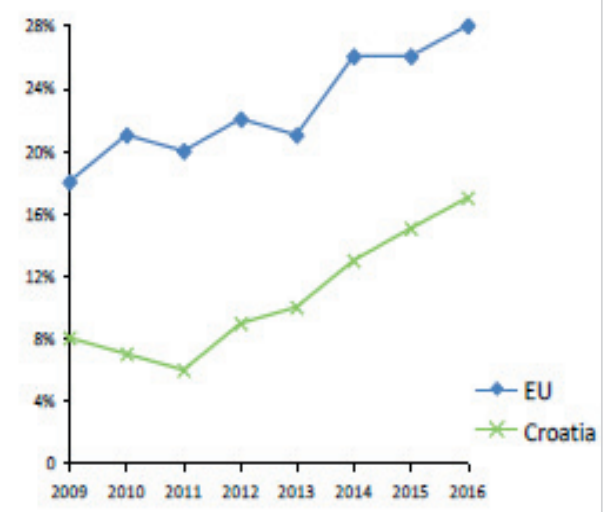

Source: EC, 2017

In the cluster analysis on eGovernment performance provided by EC (2016) Croatia was in group 4. „Group 4 is composed of lower income countries with populations that are less urbanised and have a relatively low level of education and relatively few digital skills; the infrastructures are not as highly developed in this group of countries; these countries also face higher perceived levels of public sector corruption" (EC, 2016)). Figure 8 shows the outcome of the cluster analysis which places Croatia in the Neophytes Cluster (low on both penetration and digitization). 
Figure 8: Clusters of e-government performance

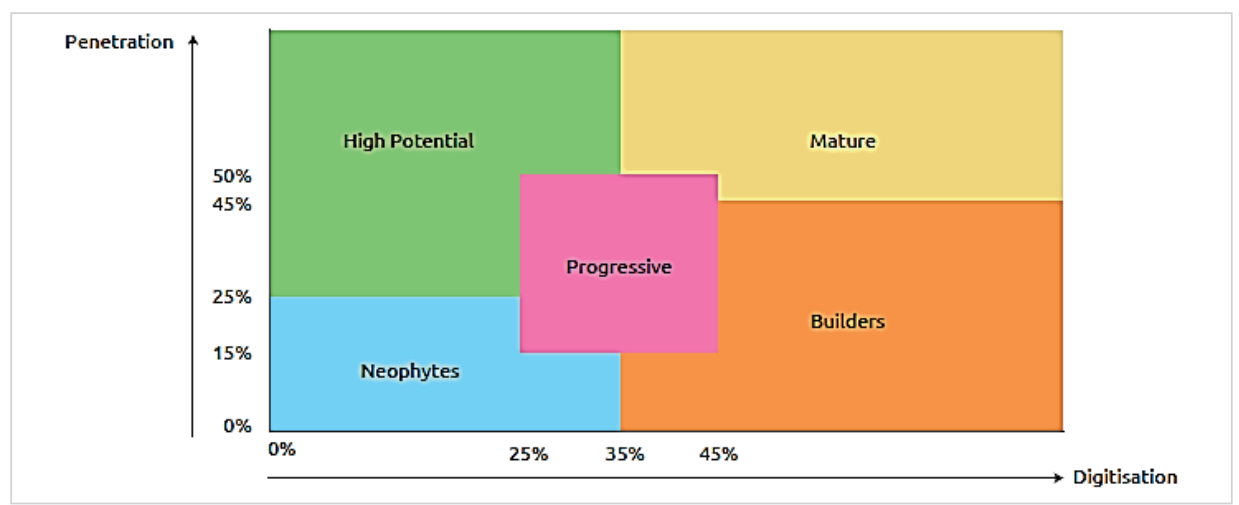

Source: EC, 2016

In the framework of developing e-Croatia 2020 Strategy, a questionnaire on citizens' satisfaction with electronic services and information in public administration (first such survey) was conducted by the Croatian Ministry of Public Administration. The purpose of the survey was to analyse which e-services citizens expect online, how citizens perceive e-government in Croatia and to identify behaviour and needs related to solving administrative issues online (Ministry of Public Administration, 2015). The sample in the questionnaire included 5100 Croatian respondents surveyed at the end of 2014 and the beginning of 2015. Results of the study are briefly presented in Figures 9, 10 and 11. Figure 9 shows that areas of greatest interest to citizens include finances, taxes, and health.

Figure 9: Most important public services and information that should be available online

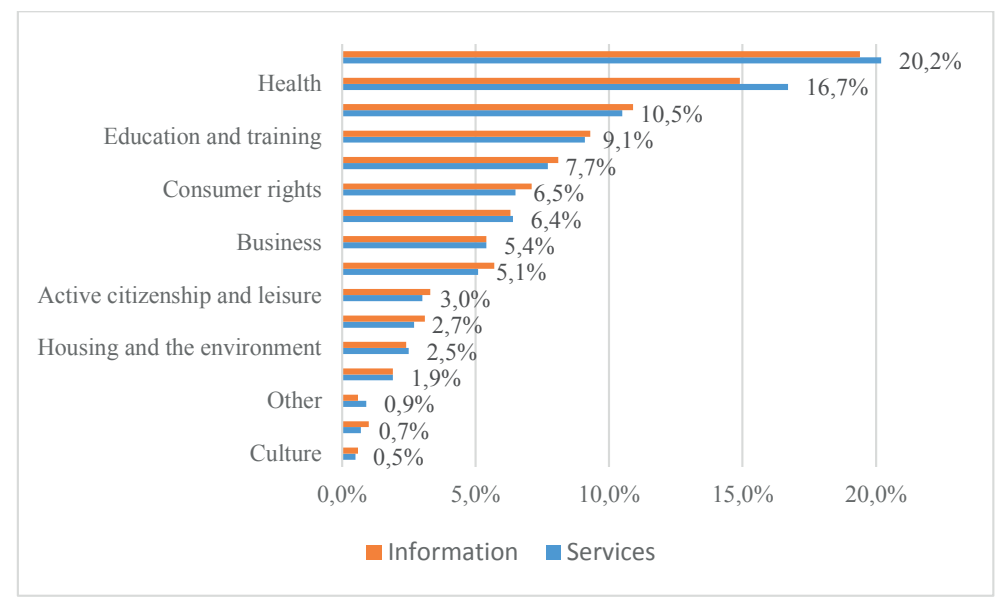

Source: https://data.gov.hr/dataset/zadovoljstvo-gradjana-elektronickim-uslugama-i-informacijama-u-javnoj-upravi (09/06/2017) 
Figure 10: Experiences of respondents in interaction with public administration

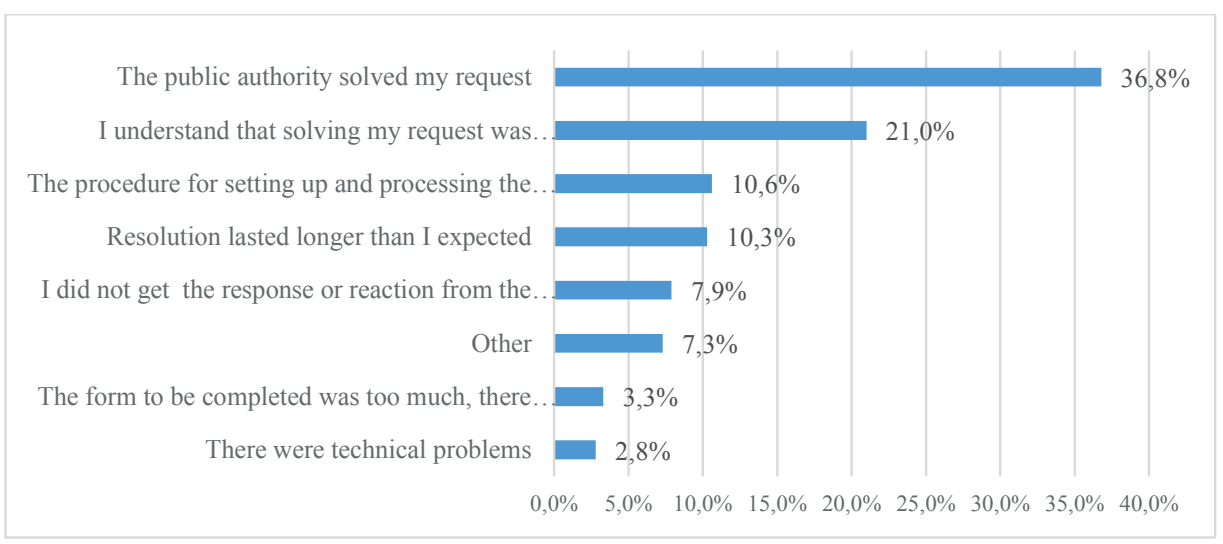

Source: https://data.gov.hr/dataset/zadovoljstvo-gradjana-elektronickim-uslugama-i-informacijama-u-javnoj-upravi (09/06/2017)

Figure 11: Perceived limitations in using e-services

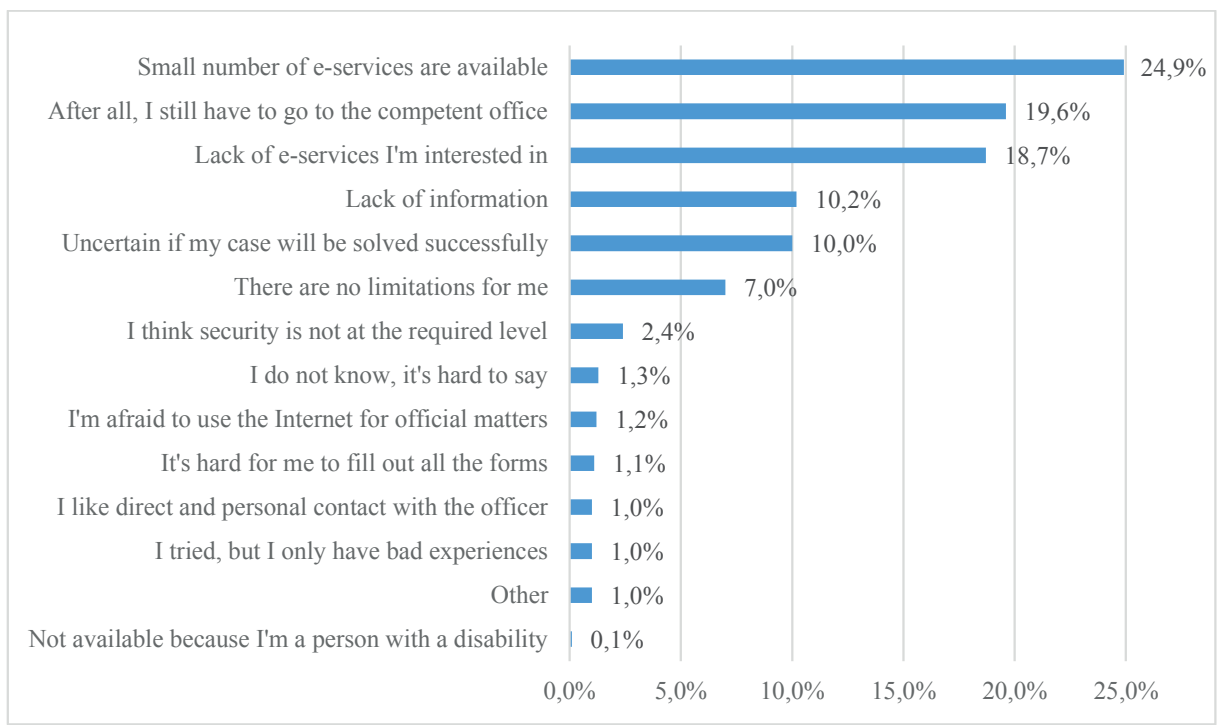

Source: https://data.gov.hr/dataset/zadovoljstvo-gradjana-elektronickim-uslugama-i-informacijama-u-javnoj-upravi (09/06/2017)

\section{CONCLUSION}

Today, according to UNDESA (2016), e-government has become a development indicator. It has helped advance the delivery of basic public services such as education, health, employment, finance and social welfare. It can play a critical role in making 
institutions more inclusive, transparent, and effective. „Further work is needed to better understand the expectations people have from eGovernment and the use they make of it so that the systems put in place help to improve people's wellbeing, respond to their needs and empower them to contribute to policy making and public services." Their report suggests that the conceptualization of e-government maturity no longer holds, as e-government goals and targets are constantly evolving in response to evolving values and needs. Croatia was ranked 37th (ranked 47th in 2014) in that global survey and was one of the countries that advanced more than 25 positions in 2016 in E-Participation Index (EPI) ranking (ranked 25th in 2016 vs. ranked 97th in 2014).

EC (2016) states that „digital transformation of government - the subtitle of the new eGovernment Action plan - can only be realised through building digital capabilities and effective digital leadership, supported by an adequately skilled public apparatus. This should be high on every public leader's agenda. If so, this could indeed prove to be the turning point for eGovernment development in Europe“. Their research puts Croatia in the Neophytes cluster. This cluster scores low on both penetration and digitization, resulting in e-government that insufficiently exploits ICT opportunities and is dependent on significant efforts to be able to move towards e-government maturity. Their conclusions and implications on specific indicators clustered within the four benchmarks for measuring progress and performance of e-government are:

- User Centricity: there is still need to focus more on user's needs - Generally speaking, governments have advanced in making public services digital, but focussed less on the quality of the delivery from the user's perspective. While the online availability of services at EU28+ level reached $81 \%$ (+9 points since 2012) and online usability $83 \%$ (+4 points since 2012), the ease of using and speed of using these services online - as perceived by the mystery shoppers - advanced poorly, increasing by only 1 percentage point since the first assessment in 2012.

- Transparency: there is progress, but not consistent and with many variations between and within countries. Despite general improvement, the implementation of good transparent procedures is still lacking in large parts of Europe.

- Cross-border services: businesses are better served, but like citizens, demand a higher usability. The borderless mobility of citizens and businesses across Europe has become even more relevant since the launch of the Digital Single Market Strategy, representing one of the pillars for its achievement. For both business and citizen cross-border online services, the lowest results are still on the demand side. Even if from the business perspective the results are slightly more optimistic, very little progress has been made in these areas and these sub-indicators lag poorly behind the others.

- Key Enablers: the engine of digital transformation is starting to make pace? Further efforts should be made by public administrations to speed up the modernisation of their processes and services with an integrated use of ICT and through a faster uptake of the key digital enablers that are necessary to effectively deliver e-government services to users and facilitate the collabora- 
tion across public organizations. The transition to full adoption of these technologies by governments and public organizations is still ongoing. Looking at single enablers, the scores are lower than showed for other indicators and their progress over the years has been relatively low or even absent.

The mentioned surveys contain enough indicators and metrics to assess Croatia's maturity model in 5 main stages proposed by Shahkooh et al. (2008). The indicators for the assessment of e-government efforts proposed by Coursey \& Norris (2008) could be an added value to that model. Metrics should consist of a survey every 2 years which would ask the national and local public entities about the changes that they attributed to their e-government efforts, which could provide a more accurate portrait of e-government than the principal model. Future research could improve the type, the quality and the quantity of data collected for the proposed analysis.

\section{REFERENCES:}

1. Almarabeh, T., \& AbuAli, A. (2010). A general framework for eGovernment: definition maturity challenges, opportunities, and success. European Journal of Scientific Research, 39(1), 29-42.

2. Andersen, K. N., Medaglia, R., Vatrapu, R., Henriksen, H. Z., \& Gauld, R. (2011). The forgotten promise of eGovernment maturity: Assessing responsiveness in the digital public sector. Government Information Quarterly, 28(4), 439-445.

3. Concha, G., Astudillo, H., Porrua, M., \& Pimenta, C. (2012). EGovernment procurement observatory, maturity model and early measurements. Government Information Quarterly, 29, 43-50.

4. Coursey, D., \& Norris, D. F. (2008). Models of e-government: Are they correct? An empirical assessment. Public administration review, 68(3), 523-536.

5. Das, A., Singh, H., \& Joseph, D. (2016). A longitudinal study of eGovernment maturity. Information \& Management, 54(4), 415-426.

6. EC, Directorate-General of Communications Networks, Content and Technology (2016). eGovernment Benchmark 2016 - A turning point for eGovernment development in Europe?

7. EC, Directorate-General of Communications Networks, Content \& Technology (2016). Open Data Maturity in Europe

8. EC, National Interoperability Framework Observatory (NIFO) community (2017). eGovernment Benchmark Report 2016 Country Factsheet Croatia, Edition 3.00

9. Fath-Allah, A., Cheikhi, L., Al-Qutaish, R. E., \& Idri, A. (2014). EGovernment maturity models: A comparative study. International Journal of Software Engineering \& Applications, 5(3), 71.

10. Madsen, С. Ø., Berger, J. B., \& Phythian, M. (2014). The development in leading eGovernment articles 2001-2010: definitions, perspectives, scope, research philoso- 
phies, methods and recommendations: an update of Heeks and Bailur. In International Conference on Electronic Government (pp. 17-34). Springer Berlin Heidelberg.

11. Shahkooh, K. A., Saghafi, F., \& Abdollahi, A. (2008). A proposed model for eGovernment maturity. In Information and Communication Technologies: From Theory to Applications, ICTTA 3rd International Conference on IEEE, 1-5.

12. Siskos, E., Askounis, D., \& Psarras, J. (2014). Multicriteria decision support for global eGovernment evaluation. Omega, 46, 51-63.

13. Šimurina, J., Hruška, M., \& Marković, M. (2008). EGovernment in Croatia: a comparative analysis. WSEAS Transactions on Business and Economics, 5(5), 222-232.

14. UNDESA, The United Nations eGovernment Survey 2016: EGovernment in Support of Sustainable Development, 2016. Available at: https://publicadministration. un.org/egovkb/en-us/reports/un-eGovernment-survey-2016 [15/03/2017]

\section{Additional sources:}

15. Croatian national portal. Available at: https://gov.hr/ [09/06/2017]

16. EU eGovernment Action Plan 2016-2020. Available at: https://ec.europa.eu/digital-single-market/en/news/communication-eu-egovernment-action-plan-2016-2020-accelerating-digital-transformation [11/05/2017]

17. Ministry of Public Administration (2015). Report: Citizen Satisfaction with Electronic Services and Information in Public Administration. Available at: https:// data.gov.hr/dataset/zadovoljstvo-gradjana-elektronickim-uslugama-i-informacijama-u-javnoj-upravi [11/05/2017]

18. UN E-Government Knowledge DataBase. Available at: https://publicadministration.un.org/egovkb/en-us/Data/Country-Information/id/42-Croatia [15/03/2017] 


\title{
INDIKATORI I METRIKE ZA MODEL ZRELOSTI E-UPRAVE U REPUBLICI HRVATSKOJ *
}

\author{
Josipa Perkov ${ }^{4}$, Ante Panjkota ${ }^{5}$ \& Ivona Mikulandra Volić 6
}

\begin{abstract}
Sažetak
E-uprava trebala bi omogućiti jednostavan pristup online servisima javne uprave, jednostavnu komunikaciju s javnim vlastima te smanjiti vrijeme i troškove raznih transakcija s javnom upravom. Trendovi pri pružanju javnih usluga u brojnim državama su implementacija i daljnji razvoj e-uprave no postoji $i$ velika razlika u upotrebi takvih usluga izmedu razvijenih i nerazvijenih država. Kao alat za procjenu, usporedbu i benchmarking razvoja i uspjeha pri implementaciji e-uprave, a s ciljem donošenja racionalnih odluka o razvoju e-uprave, koriste se modeli zrelosti. U modelima zrelosti e-uprave posebna pažnja treba biti usmjerena na kompleksnost e-uprave u sociološkom, tehnološkom $i$ organizacijskom smislu. Ta kompleksnost utjecala je na razvoj brojnih modela zrelosti e-uprave s raznim indikatorima i metrikama. Pregled literature daje odgovore na sljedeća istraživačka pitanja: Koji se indikatori i metrike koriste u najčešće korištenim i/ili diskutiranim modelima zrelosti e-uprave? Jesu li ti indikatori i metrike primjenjivi za e-upravu u Republici Hrvatskoj ili postoji potreba za posebnim modelom? Cilj ovog rada je istaknuti one indikatore i metrike kojima se mogu objektivno mjeriti određene vrijednosti e-uprave te istaknuti one koje zasad nemaju apsolutnu mjeru. Rezultat ovog rada su opisani $i$ analizirani indikatori i metrike korišteni u nekim od najčešće korištenih i/ili diskutiranih modela zrelosti e-uprave. Sintetiziranjem zaključaka ovaj rad daje smjernice za razvoj modela zrelosti e-uprave u Republici Hrvatskoj.
\end{abstract}

Ključne riječi: e-uprava, online servisi, indikatori, metrike, model zrelosti.

\section{JEL klasifikacija: H11}

\footnotetext{
Rad je prezentiran na 2. Međunarodnoj konferenciji "Business \& Entrepreneurial Economics-BEE2017" koja je održana na Brijunima od 24. do 26. svibnja 2017. godine (www.bee-conference.com)

4 Josipa Perkov, mag. math., viši predavač, Odjel za ekonomiju, Sveučilište u Zadru, Zadar, Hrvatska, E-mail: jperkov@unizd.hr

5 Dr. sc. Ante Panjkota, poslijedoktorand, Odjel za ekonomiju / Pomorski odjel, Sveučilište u Zadru, Zadar, Hrvatska, E-mail: apanjkot@unizd.hr

6 Ivona Mikulandra Volić, mag. oec., viši predavač, Odjel za ekonomiju, Sveučilište u Zadru, Zadar, Hrvatska, E-mail: imvolic@unizd.hr
} 